DOI: $10.30525 / 978-9934-588-61-7-21$

Hryniuk D. Yu. Candidate of Geographical Sciences, Associate Professor Taras Shevchenko National University of Kyiv

Hryniuk T. A. Candidate of Geographical Sciences, Associate Professor

National Pedagogical Dragomanov University

\title{
ECONOMIC AND GEOGRAPHICAL ASPECTS OF THE STUDY OF THE COMPETITIVENESS OF THE REGION
}

\section{Summary}

The aim is to offer scientific approaches to economic and geographical research of the region's competitiveness and to substantiate practical recommendations for its improvement in the region.

For the first time, a complex social and geographical analysis of competitiveness has been carried out and center-periphery laws of region competitiveness have been established. In this case, it is possible to identify the territorial differences of the competitive advantages and positions that they occupy in terms of productive financial, labor, and natural resource potential and the potential of social and demographic development and the territorial components of the center-periphery system of the region.

The research offers four stages of the region's competitivenes, which are theoretical and methodological, evaluative, analytical, and synthetic stages, and one of the main methods for assessing the region competitiveness, which is based on the rank comparison methods. The most competitive territory is determined by ranking according to the integral index.

The presented methodological approach in research of competitiveness of the region can be used in the course of similar researches of regions of any state.

\section{Introduction}

The competitiveness of the country and the region is one of the most relevant areas of modern economic, social and geographical research. In the «State Strategy of Regional Development up to 2020» the main aim of 
regional development in Ukraine is to create conditions for dynamic, balanced development of the regions of Ukraine in order to ensure social and economic unity, increase competitiveness of the regions, intensify economic activity, improve living standards, compliance with state-guaranteed social and other standards for every citizen regardless of place of residence. The main goal is specified on the territorial direction in ensuring uniform and balanced development of territories, development of interregional cooperation, prevention of deepening socio-economic disparities by forming "growth points», intensification of local economic initiative and strengthening of rural potential, forecasting the development of the state and regions.

Thus, regional development is closely linked to the task of achieving regional competitiveness. It is based on deepening the specialization of the region and the effectiveness of the established interregional and intra-regional ties. Determining factors that identify the regional competitiveness are geographical location (especially about markets, sources of raw materials, labor, research centers, etc.), the availability of quality labor, business and small business development, access to information, infrastructure development (primarily market, logistics), the effectiveness of regional development management. Factors of production retain a significant role in the development and increased competitiveness of modern regions. The latter depends on the expansion and development of industrial enterprises. In modern conditions, increasing the competitiveness of the region by strengthening its production potential is determined by the qualification of production management, availability of financial resources, cooperation between research institutions and business, ensuring innovative development on this basis. Entrepreneurship development is a key factor in ensuring the competitiveness of regions. It allows to meet the resource needs of the region, to increase the budget of the region and its local governments, to improve the level of public services, to develop retail trade, logistics and more. At the same time, it is impossible to achieve a high level of competitiveness of the region in modern conditions only due to the development of the production segment. It increasingly depends on social development.

\section{Part 1. Economic and geographical essence of the region's competitiveness}

Scientists identify the growing influence of new conditions and factors of regional development (social and environmental), which are changing in a powerful segment of influence as the resettlement of the population and production and economic development in general. The research factor is becoming increasingly important in achieving a high level of competitiveness in the region. The region, where research institutes, universities with a practical orientation and close relation with the private sector are situated, is becoming a pole of growth, i.e., a center of high-tech production and innovative services. Increasing of its competitiveness is determined by the influx of highly qualified and creative staff, innovation-oriented companies. Their long-term success largely depends on the ability to anticipate new consumer and technological trends, diversify the structure of production and 
services, quickly restructure the production infrastructure, mobilize the necessary intellectual resources.

Despite the widespread use of the concept of competitiveness in research, the discourse on its interpretation and practical implementation of the basic principles of increasing the competitiveness of the territory is still developing. The Ukrainian and foreign scientists emphasize on various components of this multidimensional category, identifying them as the main criteria. The range of definitions varies from purely technological, arising from the expanded interpretation of the competitiveness of the firm, to the detailed socioeconomic, which consider competitiveness as a generalized indicator of the stability of the socio-economic system of the country.

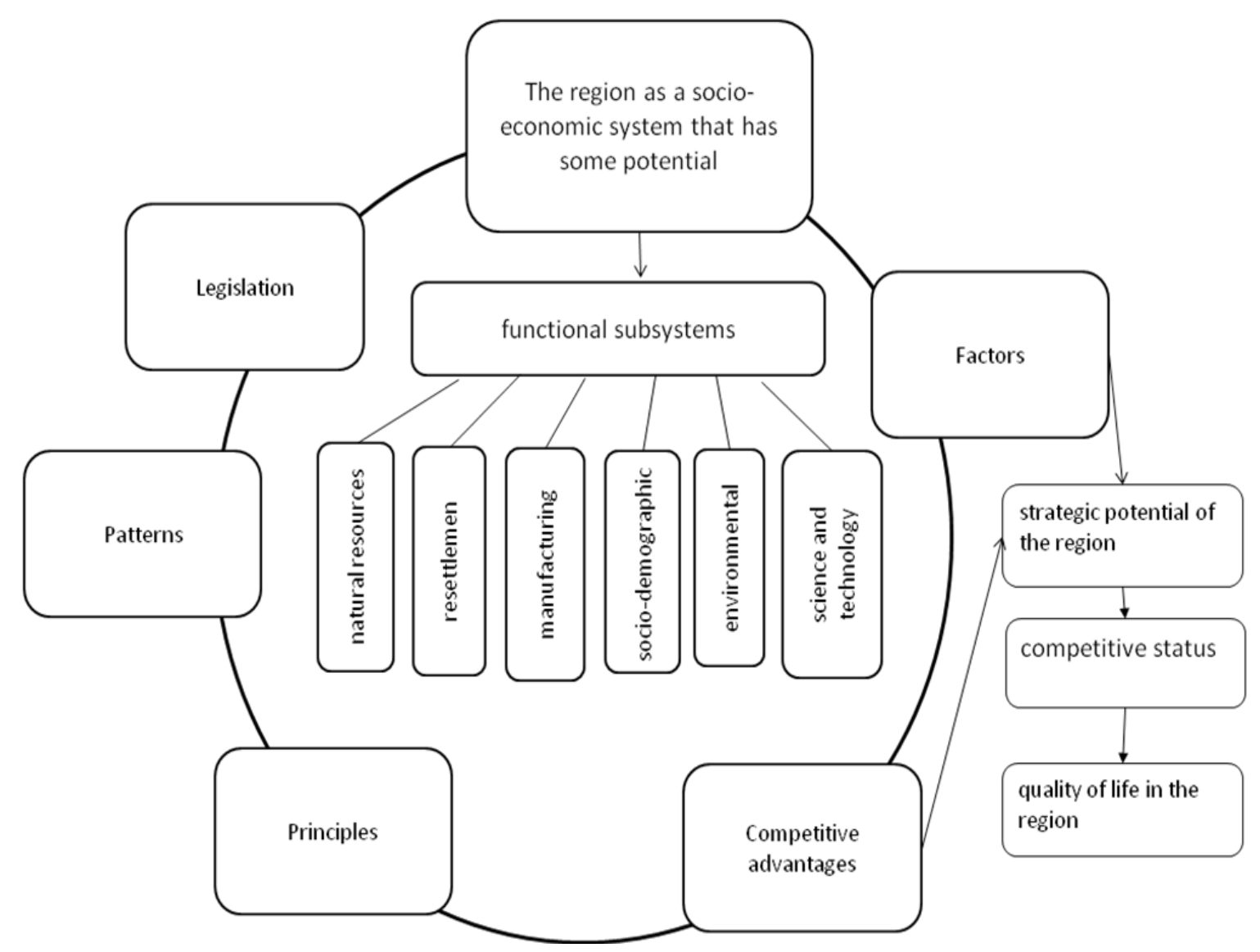

Figure 1. Theoretical approaches to the study of regional competitiveness

Source: developed by the authors

This study is based on the theoretical developments of economists and geographers: M. Porter, M. Enright, E. Reinert, P. Romer, K. Freeman, J. Becattini, E. Bergman, J. Dunning, R. Kaplinsky, P. Krugman, J. Sachs, V. Geets, A. Galchinsky, R. Fatkhutdinov and B. Asheim, I. Gukalova, F. Zastavny, S. Zapototsky, S. Ishchuk, S. Lisovsky, E. Marunyak, K. Mezentsev, Ya. Oliynyk, M. Pistun, V. Rudenko, L. Rudenko and others.

It is belived that at the level of the national economy, the object of competitiveness is the conditions of social production (J. Sachs, 1999). It is 
defined by the formation of an environment that has the most effective structure, institutions and policies that provide the nation with the necessary opportunities for competition. The competitiveness of the national economy as a characteristic of the state of the economic system has internal origins: it is born and developed in the internal environment of the country in the process of competition between the subjects of economic relations.

The spatial organization of the economy, in a broad sense, covers many aspects of the territorial division of labor, the location of productive forces, the settlement of people, the relationship between society and the environment. According to $\mathrm{M}$. Porter, the competitiveness of the region is determined by the productivity of the regional resources (primarily labor and capital) compared to other regions, which is reflected in the value of gross regional product (GRP) per capita, as well as in its dynamics [9]. According to O.Z. Selezny, the competitiveness of the region is a location of the region due to economic, social, political and other factors and its individual producers in domestic and foreign markets, which is reflected in indicators that adequately characterize this state and its dynamics.

The level of development of any country reflects its competitiveness compared to others, and competitive countries have a better chance of selfsustaining development (i.e., competitiveness and economic development are interrelated categories). The indicator of the level of economic development is an integral indicator for comparing different groups of countries (regions) to determine their competitive advantages. It is based on the method of ranking territories according to certain indicators, criteria for selecting leading regions are determined.

When determining the level of competitiveness, both traditional factors (location of population, production, raw materials, transport, consumption of materials and energy, labor resources, infrastructure development, etc.), as well as new ones (labor market structure, environmental constraints, intangible location factors, production of innovative products etc). Recently, much attention has been paid to the development of entrepreneurial activity, intensity, diversity and quality of levels of cultural activities and recreational services, creative climate; people's attachment to their locality, etc. As intangible factors are more difficult to be quantified than material ones, this has required the creation of new information and analytical tools.

Based on the analysis of statistical materials of the industries of eight industrialized countries, M. Porter (1990) has proposed an original concept of competitive advantage, based on the idea of the so-called "competitive rhombus», which reveals four properties (determinants) of the country that form a competitive environment, in which companies of this country operate. «Competitive rhombus» characterizes the system of determinants of competitive advantage, the components of which (as in any system), being in interaction, create the effect of emergence (integrity), so strengthen or weaken the potential level of competitive advantage of firms in this country. Each of the determinants presented in the scheme is formed in a special way to reflect the influence of the other determinants. These determinants are: factor 
parameters (left corner of the rhombus); firm strategy, their structure and rivalry (the top of the rhombus); demand parameters (right corner of the rhombus); related and supporting areas (lower corner of the rhombus).

One of the key categories that reveals the direction of realization of competitive advantages is the category of «competitive positioning» described by M. Porter [9]. The competitive position of the region is determined by geographical and economic factors of its development. They include a favorable geographical position (primarily geoeconomic), unique natural resources, a deep level of specialization of production (including through the use of natural resources), highly developed logistics and integrated infrastructure, favorable market conditions, human capital, efficient government regional policy and public management at different territorial hierarchical levels, favorable environmental situation.

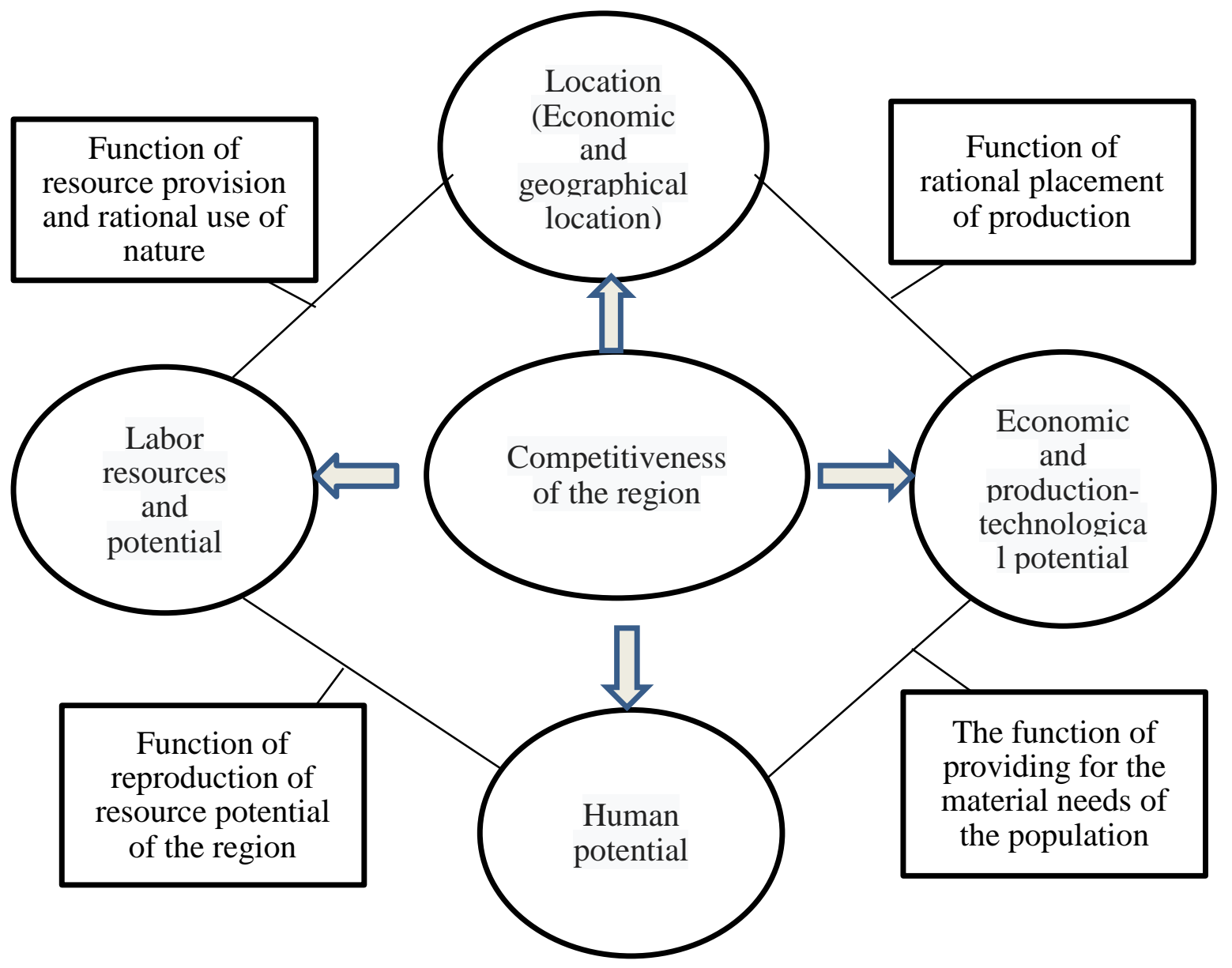

Figure 2. Determinants of the region's competitiveness and their functionality

Source: developed by the authors on the basis of the Michael Porter's «National Rhombus»

The modern scientific approaches in the study of competitiveness include the work of the Ukrainian scientist S.P. Zapototskyi [7]. According to the scientist, the content of competitiveness is based on the functions of the region, such as the organization of life, production of goods and services, etc. 
Competitiveness of the region is the ability of the region as a system to function in a market environment, to ensure the processes of effective reproduction of people, conditions and resources effectively. The analysis of regional competitiveness should take into account the fact that the development of regional competitiveness includes four stages (levels) production, investment, innovation, wealth.

Summarizing the existing theoretical provisions from a social and geographical point of view and taking into account all the above definitions, we propose our own interpretation of competitiveness (in general) and the competitiveness of the region as a subject of this study.

Competitiveness is an integrated interdisciplinary concept that characterizes the property of a particular social and geographical object (enterprise, industry, region, country) of progressive innovative development based on the benefits of social and geographical factors under a number of economic, social and geographical laws of development, and directed to improve the quality of life of the population. Competitiveness of the region is a multifaceted integrated concept that reveals the state, process and result of the development of the territory as an innovative socio-economic system with a certain potential, able to function effectively in a market environment based on social and geographical factors, considering the influence of a number of laws, which is motivated by needs of improving the quality of life of the population.

The level of competitiveness of a region largely depends on its distance and geographical location. The distance from economically developed areas and centers determines the availability of markets for goods. It is important to be close to raw materials, logistics infrastructure of global and regional importance. In this aspect, we can analyze the relationship of the region in relation to the networks of the settlement system, production, social and market infrastructure. Unique natural resources remain a good basis for forming a competitive position. This is true both for traditional natural resources and for relatively recently involved regions (solar insolation, wind energy, biogas, etc.).

The availability of the traditional resources of the territory, the attraction of new ones, the increase of its potential, now and in the future, will be based on a well-known factor - a deep level of specialization of production. Highly developed logistics and integrated infrastructure retain its importance as a condition for forming a competitive position in the region. Without the development of these components of production systems, it is impossible to achieve a sufficient level of competitiveness for the development of the territory. When providing the parallel development of other modern components of the success of the territory - high human capital, access to knowledge, etc. - highly developed logistics and infrastructure are a reliable support for the formation and consolidation of the region's competitiveness. 


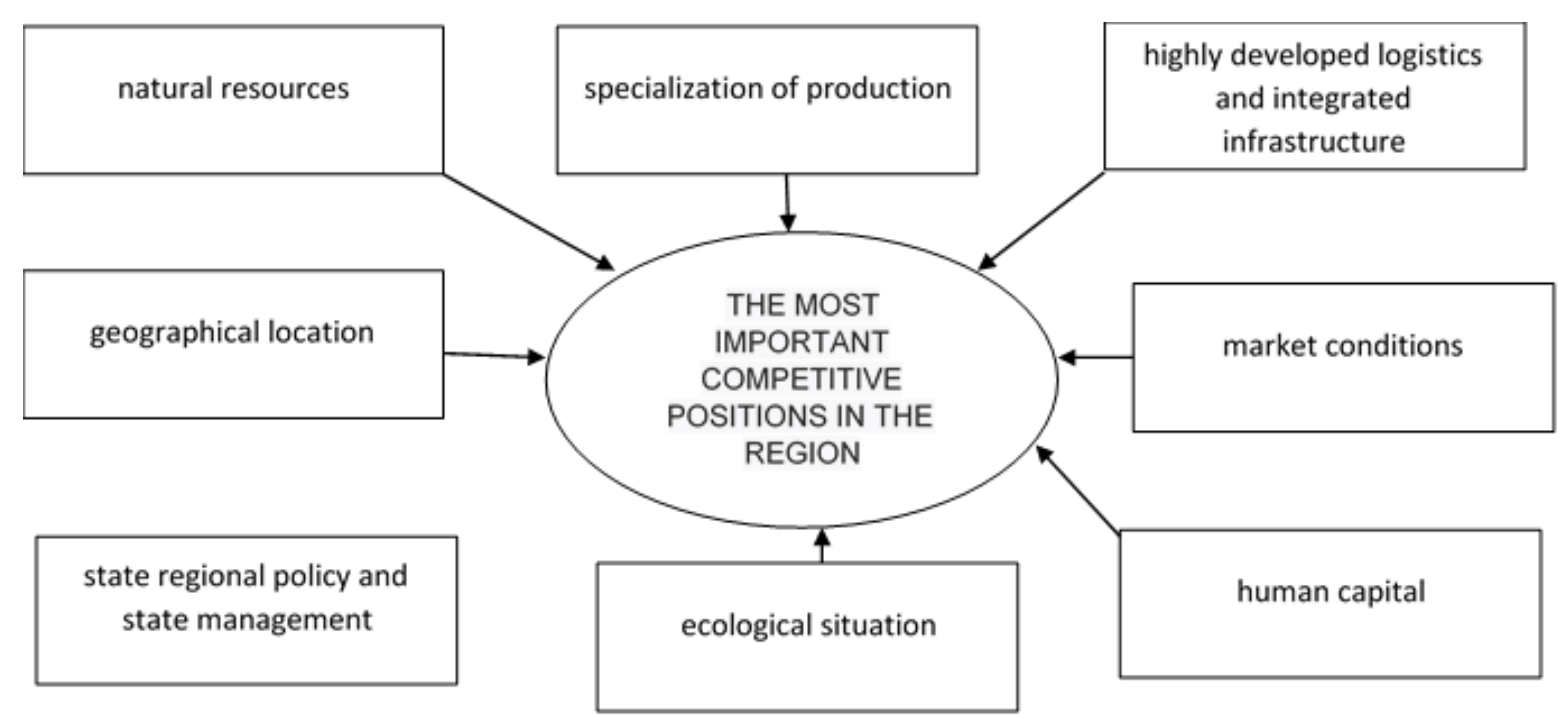

Figure 3. Competitive positions of the region

Source: generalized by the authors for $[1 ; 4 ; 8]$

Favorable market conditions are the main regulator of mass production in the modern world. The struggle for key markets is being intensified and leads to an increase of acute military conflicts in the 21 st century and numerous political confrontations on the main directions of development of modern humanity. In our opinion, the basis for the formation and maintenance of the region's competitiveness remains human capital. Entrepreneurial activity, availability of information and knowledge, formation of innovative processes on this basis, technologies, goods and services in the long run will determine the contours of the region's competitiveness. We are convinced that this is a basic «internal» factor in the development of the region, which outlines the importance of the location. Therefore, the region is a phenomenon in the environment of competition between the state economy and world economies.

Effective state regional policy and state management at different territorial hierarchical levels are designed to stimulate the focus of sufficient revenues to maintain conditions for increasing human capital, involving the population in socially important processes, especially management, aimed at territorial development. Among the main efforts in this direction we should point out the maximum availability of information and impact on information flows.

Finally, among the main components of the formation of the region's competitiveness, the environmental situation should be singled out. Increasing human capital in modern conditions without raising human living standards to achieve significant competitive positions in the region is impossible. The spatial content of achieving the competitiveness of the territory is described by traditional for economic and geographical analysis theories and concepts of development and location - the center-periphery, the growth poles of Perroux and others $[2 ; 3 ; 5 ; 6]$.

Regions differ significantly not only in natural resource and economic potential, but also in political and economic, administrative, managerial and other factors, the effectiveness of local authorities and self-government, the 
strategy of producers. That is why in scientific works on regional development, attention is paid to the institutionalization of the process of regional development. In particular, to ensure the competitiveness of the regions, the leading role is given to the policy of regional authorities, which determines the legal resource, by which the authorized economic entity acts in accordance with the law. For local authorities and management, the scope of competencies is derived from the processes of deconcentration and decentralization of public administration that take place in the country. The policy of decentralization, typical for the developed countries of the world, however, and implemented in Ukraine, is aimed at building the capacity and responsibility of the regional and local levels of government to maintain conditions for production growth, maintaining high living standards. The key tool for the development of the territory is its competitiveness.

The formation of new territorial and administrative entities and the strategy and programming of the development of existing ones, from the standpoint of social geography, is based on the region's perception of objectively existing entities with centers (cores) that collect or distribute resources. The location of production, the concentration of certain industries at the present stage do not coincide in their boundaries with the administrative and territorial units. Fuel and energy, forestry, machine building, agroindustrial, agricultural and other branch districts are partially preserved. H. Ridhardson believed that the program regions, created on the basis of objectively formed nodal areas, are ideal for planning activities. The task of macro- and meso-zoning is to strengthen the regulation of basic economic proportions and ensure a rational territorial division of labor. Organizational and economic mechanisms to ensure their functioning are the object of state targeted comprehensive programs of their socio-economic development $[2 ; 9 ; 10]$.

\section{Part 2. Methodological approaches to the study of the competitiveness of the region}

The competitive advantage of firms is created and maintained in close connection with local conditions. Despite the globalization of industries, the role of the country and the region of the company's base has recently strengthened, the success of firms in competing with competitors depends primarily on the state of affairs in the country and the region. In turn, countries and regions are developing in a competitive environment. The study of the competitiveness of the region requires the development and justification of the methodological apparatus. The research methodology is an algorithm (order) of scientific knowledge of the region's competitiveness, based on general scientific and special principles, and the goal is achieved through the use of a set of research methods. Social and geographical study of the competitiveness of the region can be carried out in four stages, presented in the form of a chain:

1. Theoretical and methodological stage;

2. Stage of assessment of factors influencing the formation of the region's competitiveness; 
3. Analytical stage (formation of goals and objectives of evaluation; verification of available indicators; selection of evaluation criteria and indicators; selection of evaluation methods; data collection and processing);

4. Generalizing (synthetic) stage.

The analysis of economic, natural and geographical, scientific and technical, administrative, social and cultural factors and location of the region in the context of its capital allowed to reveal the reasons that determine the strategic directions of competitiveness and determine the nature of territorial organization of the region.

At the third analytical stage, the modern structure of the economic complex of the region from the standpoint of competitiveness, is investigated. The study has been conducted at the meso level (compared to other regions), intraregional level (compared to individual administrative districts). A structural analysis of the region's competitiveness also has been carried out.

As it is known, the structure is a set of stable links within the scientific object of study, ensuring its integrity, on the one hand, and the preservation of basic internal properties in various internal and, on the other hand, external transformations (changes). The implementation of geographic and mathematical analysis has been based on the use of factor analysis. Let us consider in more detail the methodology on the example of human capital analysis, as one of the main bases for the formation of the region's competitiveness. The level of human capital development is an important condition for building civil society and increasing the competitiveness of regions and the country as a whole. That is why it is important to study the current state of this capital for each region to understand in what conditions and under the influence of what factors the regional competitiveness of human capital is formed.

In modern science, there are many different approaches to the interpretation of human capital, which generates even more diverse indicators of measuring the competitiveness of its development. One of such approaches, which is based on the indicators of official statistics of the State Statistics Committee of Ukraine, has been proposed by O.M. Hinda and S.M. Hinda. The authors believe that in modern conditions, the main components of human capital for Ukraine are education capital, health capital and cultural capital. This choice of the main components of human capital is due to the fact that its formation and development depend on many factors: different productive abilities, knowledge, health, access to information, occupational mobility, needs, desires to acquire and use knowledge, culture, etc. A matrix of indicators has been proposed that is available for widespread use. They sufficiently fully analyze and assess the state of the main structural components of human capital. However, the search for these indicators in official sources in 2016 has led to a modification of the matrix of indicators (Table 1). This has been necessary because some indicators are estimated, that is derived from the official indicators presented on the website of the State Statistics Committee of Ukraine. 
Grouping of indicators by aspects of human potential

\begin{tabular}{|c|c|l|}
\hline $\begin{array}{c}\text { Aspect of } \\
\text { human capital }\end{array}$ & \multicolumn{2}{|c|}{ Indicators for assessing the competitiveness of human capital } \\
\hline \multirow{4}{*}{$\begin{array}{c}\text { Education } \\
\text { capital }\end{array}$} & $x_{1}$ & $\begin{array}{l}\text { the number of university students of all levels of } \\
\text { accreditation per 10 thousand population, persons }\end{array}$ \\
\cline { 2 - 3 } & $x_{2}$ & $\begin{array}{l}\text { the number of teaching staff who have a degree per } \\
\text { university, persons }\end{array}$ \\
\cline { 2 - 3 } & $x_{3}$ & population with higher education per 1,000 people \\
\hline \multirow{4}{*}{ Health capital } & $x_{4}$ & $\begin{array}{l}\text { morbidity of the population by classes of diseases as of the } \\
\text { end of the year per 100 thousand population, persons }\end{array}$ \\
\cline { 2 - 3 } & $x_{5}$ & $\begin{array}{l}\text { provision of hospital beds per 10 thousand population, } \\
\text { persons }\end{array}$ \\
\cline { 2 - 3 } & $x_{6}$ & $\begin{array}{l}\text { number of doctors of all specialties per 10 thousand } \\
\text { population, persons }\end{array}$ \\
\hline \multirow{2}{*}{$\begin{array}{c}\text { Culture } \\
\text { capital }\end{array}$} & $x_{7}$ & $\begin{array}{l}\text { provision of the population with cultural and art institutions } \\
\text { per 100 persons, units }\end{array}$ \\
\cline { 2 - 4 } & $x_{8}$ & $\begin{array}{l}\text { attendance by the population of cultural and artistic } \\
\text { institutions on average per year per 100 people }\end{array}$ \\
\hline
\end{tabular}

The calculated indicators of human capital competitiveness include:

- the number of people with higher education per 1,000 people;

- the number of teaching staff who have a degree, per university (colleges, technical schools, universities, academies, institutes), persons;

- provision of the population with cultural and art institutions per 100 thousand people, units (calculated as the sum of the number of libraries, clubs, museums, theaters, concert organizations and professional creative groups (including philharmonics, concert and pop associations, etc.), divided by the average annual population);

- attendance by the population of cultural and artistic institutions on average per year per 100 people (calculated as the sum of the number of readers in libraries, participants in club formations, museum visitors, theater visitors and the number of concert listeners divided by the average annual population).

Thus, although, these indicators of human capital competitiveness in the regional context are relative, they are incommensurable. In order to achieve symmetry, we apply rationing by linear scaling, which will help in data analysis and identification of statistical patterns. This method consists of converting the values of the indicator into an estimated scale from 0 to 1 (the scale depends on the scale of the sample). This method takes into account both stimulating and disincentive effects of the index of human capital development. Similarly, the index of competitiveness of the economic potential of the region was calculated in the work. The study requires a certain sequence of steps. This stage includes: formation of goals and objectives for assessing the level of competitiveness of the region; verification of available indicators; choice of alternatives for comparison; selection of evaluation 
criteria and indicators; choice of evaluation methods; data collection and processing.

The objectives of the competitiveness assessment depend on who initiated the competitiveness and where the results will be used. Potential investors, first of all, will be interested in competitiveness of the region on factors of production, investment and business climate, ecological indicators, etc. For public executive authorities, the purpose of an estimation can be the definition of contribution of each region in the process of increasing competitiveness of the country.

Regional (local) authorities are interested in a comprehensive assessment of the region's potential, identifying its competitive advantages and factors hindering development, in order to develop (adjust) the development strategy of the region. Other goals may be: positioning a particular region among others in terms of the impact of the region's competitiveness on the competitiveness of the country, neighboring regions, improving the image of the region and others.

Different types of data can be used to assess the competitiveness of a region. Data from official sources (the State Statistics Committee of Ukraine, ministries, agencies, independent analytical companies) can be used. Assessing the competitiveness of a region involves comparing one region with another on a number of indicators, so the indicators that are used to assess should be compared with each other. In many cases, existing data can be used, while in others special studies are needed.

The choice of criteria and indicators for assessing the competitiveness of the region also depends on the objectives of the study. The most commonly used assessment is based on investment criteria, the level of economic development (potential) of the region, socio-economic and environmental indicators. Depending on the objectives of the evaluation, both integrated and partial indicators of the region's competitiveness can be selected. Integrated indicators are used to work on creating a favorable image of the region, determining the contribution of the region to the economic development of the country. Partial indicators characterize the competitiveness of the region in specific areas (criteria). Regions with a low overall level of competitiveness may be competitive in some respects from the point of view of potential investors.

The integrated index of competitiveness of the region is calculated on the basis of two consolidated indices: 1) competitiveness of the administrative and territorial units of the region and 2) institutional development of the region. Each of the consolidated indices includes several components. The consolidated index of institutional development includes indices that characterize the impact of regional economic conditions on the functioning of the administrative and territorial units of the region. Consolidated index of competitiveness of the administrative and territorial units of the region includes indices that characterize the impact of the economic condition of the administrative and territorial units on the general economic conditions of the region. 


\section{Grouping of indicators of economic potential by thematic blocks}

\begin{tabular}{|c|c|c|}
\hline $\begin{array}{l}\text { Thematic } \\
\text { blocks of } \\
\text { economic }\end{array}$ & \multicolumn{2}{|r|}{ Indicators for assessing the competitiveness of economic potential } \\
\hline \multirow{5}{*}{$\begin{array}{l}\text { Basic } \\
\text { infrastructure }\end{array}$} & $x_{1}$ & $\begin{array}{l}\text { density of public roads with a hard surface, } \mathrm{km} \text { per } 1000 \mathrm{~km}^{2} \text { of } \\
\text { territory }\end{array}$ \\
\hline & $x_{2}$ & density of public railways, $\mathrm{km}$ per $1000 \mathrm{~km}^{2}$ of territory \\
\hline & $x_{3}$ & $\begin{array}{l}\text { share of construction of engineering structures in general } \\
\text { construction works of the region, } \%\end{array}$ \\
\hline & $x_{4}$ & freight turnover of motor transport, million tkm \\
\hline & $x_{5}$ & passenger turnover of buses, million pass $\mathrm{km}$ \\
\hline \multirow{5}{*}{$\begin{array}{l}\text { Production } \\
\text { and financial } \\
\text { potential }\end{array}$} & $x_{6}$ & GRP per year per capita, UAH \\
\hline & $x_{7}$ & $\begin{array}{l}\text { volume of sold industrial products (goods, services) per capita, } \\
\text { UAH }\end{array}$ \\
\hline & $x_{8}$ & $\begin{array}{l}\text { labor productivity in agricultural enterprises per person } \\
\text { employed in agricultural production, UAH }\end{array}$ \\
\hline & $x_{9}$ & share of profitable enterprises in the region, $\%$ \\
\hline & $x_{10}$ & capital investments per person, UAH \\
\hline \multirow{3}{*}{$\begin{array}{l}\text { Innovation } \\
\text { potential }\end{array}$} & $x_{11}$ & $\begin{array}{l}\text { total number of innovative enterprises in the industry of the } \\
\text { region, units }\end{array}$ \\
\hline & $x_{12}$ & $\begin{array}{l}\text { total volume of sold innovative products, which is new for the } \\
\text { market and for the enterprise for the year in industry, thousand } \\
\text { UAH }\end{array}$ \\
\hline & $x_{13}$ & total innovation costs for the year in industry, thousand UAH \\
\hline \multirow{5}{*}{$\begin{array}{l}\text { Potential of } \\
\text { social and } \\
\text { demographic } \\
\text { development }\end{array}$} & $x_{14}$ & $\begin{array}{l}\text { total migration growth / reduction ratio, per } 10 \text { thousand of the } \\
\text { available population }\end{array}$ \\
\hline & $x_{15}$ & total fertility rate per woman \\
\hline & $x_{16}$ & infant mortality rate per 1,000 live births (under 1 year of age) \\
\hline & $x_{17}$ & $\begin{array}{l}\text { the number of university students per } 10 \text { thousand population, } \\
\text { persons at the beginning of the school year }\end{array}$ \\
\hline & $x_{18}$ & disposable income per capita, UAH \\
\hline \multirow{5}{*}{$\begin{array}{c}\text { Labor } \\
\text { potential }\end{array}$} & $x_{19}$ & $\begin{array}{l}\text { the share of economically active population aged } 15-70 \text { years of } \\
\text { the total population of the region aged } 15-70 \text { years, } \%\end{array}$ \\
\hline & $x_{20}$ & $\begin{array}{l}\text { unemployment rate of the population aged } 15-70 \text { years (accor- } \\
\text { ding to the methodology of the International Labor Organization), } \\
\% \text { of the economically active population aged } 15-70 \text { years }\end{array}$ \\
\hline & $x_{21}$ & employers need workers to fill vacancies, thousands of people \\
\hline & $x_{22}$ & workload per vacancy (vacant position), persons \\
\hline & $x_{23}$ & average monthly salary, UAH \\
\hline \multirow{3}{*}{$\begin{array}{l}\text { The potential } \\
\text { of } \\
\text { international } \\
\text { integration }\end{array}$} & $x_{24}$ & $\begin{array}{l}\text { foreign direct investment (equity) per capita at the end of the } \\
\text { year, USD }\end{array}$ \\
\hline & $x_{25}$ & export of goods, million USD \\
\hline & $x_{26}$ & export of services, million USD \\
\hline \multirow{4}{*}{$\begin{array}{l}\text { Natural and } \\
\text { ecological } \\
\text { potential }\end{array}$} & $x_{27}$ & current expenditures for environmental protection, million UAH \\
\hline & $x_{28}$ & capital investments in environmental protection, million UAH \\
\hline & $x_{29}$ & $\begin{array}{l}\text { emissions of pollutants into the atmosphere from stationary } \\
\text { sources of pollution, thousand tons }\end{array}$ \\
\hline & $x_{30}$ & $\begin{array}{l}\text { share of land areas of reserves and national nature parks from } \\
\text { the area of the region, } \%\end{array}$ \\
\hline
\end{tabular}


Consolidated indices are calculated on the basis of partial indices, which in turn are formed on the basis of socio-economic indicators or expert assessments. The offered list of indicators is formed proceeding from the indicators calculated and resulted by statistical offices.

Having clarified the purpose, defined indicators and estimated information resources, it is possible to pass to a choice of methods of an estimation of competitiveness of region. They will depend on the tasks, time and budgetary frames, on the possibility of evaluation.

It is problematic to make a reliable comparative measure of competitiveness in a generalized form due to the impossibility to reduce to a common denominator the various processes reflected in the functional parameters. At the same time, competitiveness, as a relative concept, is defined in comparison with other studied objects. Therefore, most approaches to assessing the competitiveness of regions are based on the methods of ranking comparisons (ranking). Thus, we are talking about the selection of many factors (indicators) that would best take into account the influence of others, and, based on which it would be possible to draw conclusions about the situation in the region and its competitiveness in relation to other regions.

The calculation of the integrated index of competitiveness of the region's economy is carried out in two stages. At the first stage, the offered indicators for regions are calculated and comparisons of regions on each of them are carried out. During the analysis, there are situations when the region may be more or less competitive according to various indicators. In this regard, it is necessary to establish the priority of indicators by determining their value. We can also define thresholds, below which the figures cannot fall. This is done so that a region with one of the indicators (for example, environmental status) below the allowable level, is not able to score high. It is advisable to set the weight for each criteria either using an expert method or using the detection of patterns. The weight of the indicator is determined by its impact on the whole group of indicators and is based on the selected objectives of the assessment.

Examination is associated with the subjectivity of expert assessments. To assess the probability of the obtained indicators, it is recommended to use the concordance coefficient, which is used to calculate the convergence of opinions of the group of experts. Correlation-regression analysis can also be used to assess the impact of a number of factors on the level of development of the region and determine their weight. After determining the weight of all indicators, it is necessary to calculate the values of partial indices, giving each of the indicators its weight.

At the second stage, each of the partial indexes is also assigned with its own weight, and based on the weighted values of the indices, the aggregate indexes are calculated, which, in turn, can be combined with different weights into an integrated indicator. Then the regions are ranked according to the integrated index, and the region with the highest score is considered to be more competitive. 
The integral index similarly consists of two aggregate indices, for each of which its weight is expertly determined. In the absence of data for all regions, we can use the method of deviation from the mean. As well as in a case with rating methods, first of all, the list of indicators (as a rule, by analogy with earlier made estimations, or an expert method) is formed. The calculation of the integrated indicator of the level of competitiveness of the region is also carried out in stages. At the first stage, the relative deviations of the basic indicators of socio-economic development are calculated. The selected indicators for each region are compared with the average Ukrainian indicators and the deviation from them (\%) is calculated. For each indicator, the region belongs to the one of several groups, each of which characterizes the degree of competitiveness of the region:

1) with very low competitiveness;

2) with low competitiveness;

3) with average competitiveness;

4) with relatively high competitiveness;

5) with high competitiveness.

The number of groups can be any. In the example, when the deviation from the average Ukrainian region belongs to the group of regions:

- by $+20 \%$ and above - with a high degree of competitiveness;

- from $+10 \%$ to $+20 \%$ - with a relatively high degree of competitiveness;

- from $-10 \%$ to $+10 \%$ - with an average degree of competitiveness;

- from $-20 \%$ to $-10 \%$ - with a low degree of competitiveness;

- from - $20 \%$ and below - with a very low degree of competitiveness.

Limit values for assigning a region for each indicator may vary, firstly, depending on the indicator, and secondly, depending on the opinions of experts who determine them. By the way, the limit values do not have to be symmetrical. At the second stage, the relative weight of each indicator is determined, and the regions are formed into groups based on a set of indicators. Data collection and processing. Assessing existing data is the first step before any additional information is collected. If the assessment requires the collection of own data, the responsible stages are the development of tools for data collection, sampling, fieldwork, data management, etc. At the fourth synthetic stage, data analysis and interpretation of results are performed. According to the results of the study of the level of competitiveness of the economic complex of the region, taking into account the links in the system «competitive enterprise - competitive region» developed the main directions of optimizing the functional and territorial structure of the region and increase efficiency in the future.

\section{Conclusions}

1. The regional aspect is essential in the overall strategy of increasing the competitiveness of the development of the EU member states. The regional innovation strategy covers all participants in the innovation process in order to constantly monitor the state of innovation development of various industries in the region in comparison with the relevant industries of 
competing regions. The competitiveness of the region is based on the deepening of the specialization of its region and the effectiveness of the formed inter and intraregional ties. Determining factors that identify the regional competitiveness are geographical location, labor force, development of entrepreneurship and small business, access to information, infrastructure development, the effectiveness of regional development management.

2. Complex spatial networks in the most developed parts of the world are undergoing continuous transformation. Social transformations of regions occur in one of the directions of society development, however, in the case of radical changes, they always lead to changes and transformations in others. Therefore, the direction of transformation can be distinguished in modern society: socialization, greening, clustering, regionalization and globalization.

3. Among the main principles of social and geographical study of the region's competitiveness there are the principles of complexity, territoriality, constructiveness, focus on energy and resource conservation, rational use of nature, priority of intellectual potential, improving social living conditions and social priorities, positioning, involvement of the region in the world.

4. Social and geographical study of the competitiveness of the region should be conducted usually in four stages: theoretical and methodological, evaluative, analytical and synthetic stages. Competitiveness, as a relative concept, is always defined in comparison with other studied objects and processes. Most approaches to assessing the competitiveness of regions are based on the methods of ranking comparisons. There are groups of factors that would take into account the influence of others, and based on which, it would be possible to draw conclusions about the development of the region and its competitiveness in relation to other regions. Then the regions are ranked according to the integrated index, and the region with the highest score is considered to be more competitive.

\section{References:}

1. Antoniuk L.L. (2004). Mizhnarodna konkurentospromozhnist krain: teoriia ta mekhanizm realizatsii. [International competitiveness of countries: theory and mechanisms of implementation. K.: KNEU, 275.

2. Bolshaia ekonomycheskaia entsyklopedyia [Great economic encyclopedia] (2007), Otv. red. N.V. Dubeniuk. M.: YeKSMO, 815.

3. Bolshoi entsyklopedycheskyi slovar [Great encyclopedic dictionary] (2004). Nauchnoe izdatelstvo «Bolshaia rossyiskaia entsyklopedyia». SPB.: «Norynt», 1456.

4. Hyzatullin Kh.N., Ponomarenko V.S., Piddubna L.I. (2007) Konkurentospromozhnist: problemy nauky i praktyky [Competitiveness: science and practice problems]. Kharkiv: VD «Inzhek», 264.

5. Gryniuk D.Iu. (2017) Synerhetychni efekty hospodarskoho rozvytku pivnichnykh raioniv Kyivshchyny za naslidkamy Chornobylskoi trahedii [Synergetic effects of Kyiv northern regions development after Chernobyl tragedy]. Heohrafycheskye aspekty ustoichyvoho razvytyia rehyonov: materyaly II mezhdunarodnoi nauchno-praktycheskoi konferentsyy (h. Homel, Belarus, 23-24 marta 2017 h.). Homel: HHU imeny F. Skoryny, 304-309.

6. Gryniuk D.Iu. (2014). Teoretychni ta prykladni aspekty investytsiino-innovatsiinoho rozvytku rehionu (na prykladi Kyivshchyny) [Theoretical and applied aspects of region 
investment and innovation development (Kyiv region)] // Heohrafiia i suchasnist. Zbirnyk naukovykh prats Natsionalnoho pedahohichnoho universytetu imeni M.P. Drahomanova. K.: NPU, 19(31), 234-250.

7. Zapototskyi S.P. (2012). Rehionalna konkurentospromozhnist: suspilno-heohrafichni zasady formuvannia [Regional competitiveness: socio-geographical formation basis]. K.: Biznes Media Konsaltynh, 424.

8. Konkurentospromozhnist natsionalnoi ekonomiky (2005) [Competitiveness of national economy]. K.: Feniks, 582.

9. Porter M. (1993). Mezhdunarodnaia konkurentsiia [International competitiveness]. M.: «Mezhdunarodnye otnoshenyia», 896.

10. Krugman P. (1994) Competitiveness: a dangerous obsessio, March-Apri, Platinum Fall Text Periodicals, 73(2), 28-44. 